改善と労動強度の軽減が実現され, 新しい採鉱システムの イメージも生まれた。

\section{$5 \cdot 4$ 収支改善}

MO Sの導入により実現された操業規模の拡大は, 中品 位鉱の増産を可能にし, その結果, およそ $10 \%$ の収入増 加となつた。

一方，原価面におふいては，ベースアップや機械設備投資 による償却費の増加を吸収し，採鉱原単価は第 3 表に示す とおり，昭和 55 年と比較して $9 \%$ の低減が達成された。

収入の増加と原価の低減によつて収支は改善され，その 上, 中品位鉱の生産参加により, マインライフの延長が図 られ,より体質の強い鉱山となつた。

謝辞 厳しい経済環境の中, 構造改善やMO S の導入を 実現し, 深沢鉣山の近代化を図れたのは, 平松京大名誉教
授, 天野秋田大教授ならびに鈴木相談役, 小森会長, 西田 社長, 近藤前常務, 成田前常務, 熊谷常務, 神野常務, 小 笠原元所長, 小竹所長をはじめ社内外各位からよせられた ご助言，ご指導の賜であり，深く感謝するとともに，日夜 献身的に業務に精励し, 協力して下さつた関係者の皆様に 患心から感謝する次第である。

$$
\text { 参考文 }
$$

1）小笠原敏也：全山トラックレス方式を採用した深沢鉱床の急速開発 について (渡辺賞論文)，日本鉱業会誌，91 [1049]，457〜 464， (1975)

2）橋本 寛他 : 深沢鉱山における通気増強について，日本鉱業会誌， $98[1130], 277 \sim 283,(1982)$

3）藤井洋二他 : 深沢鉱山における採掘主作業の機械化と大型化につい $\tau$ ，日本鉱業会誌，99[1142]，263～268，(1983)

\title{
Modernization by Development of Mine On-line System at Fukasawa Mine
}

\author{
by Yoji FUJII ${ }^{1}$
}

Fukasawa Mine is a kuroko mine, developed and operated with a fully trackless sytem. The cut and fill method with artificial roofing is applied; about 20 drift headings spread throughout an area of $2.0 \mathrm{~km}$ by $1.0 \mathrm{~km}$ and are generally being worked on to produce $26,500 \mathrm{t}$ of crude ore per month. These drift driving works progress in cycles of drilling and blasting, mucking, and timber supporting.

The development of Mine On-Line System (MOS) is composed of innovations on mining machines and underground communication; it aims to establish the optimum combination of workers, machines, and drift headings. Innovations in mining machines include the development of cross-cut jumbos, timbering machines, and scale-up of loaders. An innovation in underground communication is the adoption of the integrated underground communication system combined with a personal computer.

A drastic improvement of worker's performance has already been observed and further improvement is expected.

The mine production is scheduled to increase to $30,000 \mathrm{t}$ per month in the near future, due essentially to the improvement of productivity as a result of the MOS project.

( 1. Former Manager of Fukasawa Operation, Hanaoka Mine, Dowa Mining Co., Ltd.)

\section{第 16 回OTC ( 海洋開発技術会議 )}

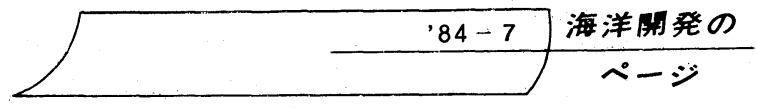

\section{半田啓 二*}

海洋開発技術会議（OTC：Off shore

Technology Conference) は, 米国鉱業会 $(\mathrm{AIME})$ ，海洋工業協会 (MTS)など関 係11学協会 (第 1 表 ) が主催する国際会議 であり，その対象分野は海底石油開発に関 連した掘削技術, 生産設備, 海洋構築物等 を中心に海洋物理, 海底地質, 海洋鉱物資 源開発，環境等広範囲にわたつている。 1969年の第 1 回会議以降毎年 5 月初旬に 米国テキサス州ヒニーストンで開催されて いるが，今年も第 16 回会議として 5 月 7 日 から 3 日間にわたつて技術論文の発表が行 なわれた。例年は技術論文の発表と同時に 技術展示会が開催され，最先端の技術や情 報が集中する，さながら海洋開発技術分野 におけるオリンピックとも言える会議であ る。しかし，今回は諸般の事情で技術論文 発表の分科会が中心の会議となり，その結
果, 会議への参加者は従来の数万人規模か ら約 2,500 人へと激減した。

ちなみに，本会議の規模を概観すると第 2表に示したように，回数を重ねるごとに 参加者数や発表論文数, 出展数が増え，第 14 回会議( 1982 年) に最高記録を示してい る*。また，OTC 実行委員会の発表による と，今回休止となつた技術展示会は次回以 降再び毎年開催となり，来年は19力国から 約 2,000 社の出展が予定されているとのこ とである***。

先述したように，今回の第16回会議は技 術論文の発表が中心となり，発表申し込み のあつた 537 編の技術論文のうち 177 編が 第了表に示した35の分科会で発表された。 日本からの論文は10編であつた。

海洋鉱物資源採掘分科会（\#24）におい ては，第 4 表に示した 6 編の論文のうち0
TC 4781 を除く 5 編について発表が行なわ れた。本分科会では熱水性鉣床に関する最 新の情報が報告された他, 通産省工業技術 院が推進している大型プロジェクト「マン ガン団塊採鉱システムの研究開発」につい て，その概要および最近の研究成果が筆者 により発表された（OTC4782）。

また，現位置土質測定技術分科会(＃６） では，「深海底土質測定装置 ( I MAGES) の開発」(OTC 4681)を含む 6 編の論文が発 表された(第5表)。OTC 4681 も工業技術 院大型プロジェクト「マンガン団塊採鉱シス テムの研究開発」の一環として公害資源研 究所が開発した装置についての発表である。

日本に扔けるマンガン団塊の研究動向, 特に，工業技術院大型プロジェクトでの研 究開発やDORDの探查活動に対する外国勢 の関心は高く,今回のこれらの発表は注意 
-The American Institute of Mining, Metallurgical, and Petroleum Engineers

第 1 表 主催学協会

をひいたもののひとつと言えよう。

この他, 注目の的となつた発表を挙げる

と，まず，海洋鉱物資源開発に関連する報

告として,

(1)熱水性鉱床の調查機器として威力を発 揮している精密音響探査機器の新技術開発

- American Institute of Chemical Engineers

- American Society of Civil Engineers

一 分科会\#14, \#20

-American Society of Mechanical Engineers

- Petroleum Division

- Marine Technology Society

- Institute of Electrical and Electronics Engineers

-Oceanic Engineering Society

- Society of Exploration Geophysicists

- Society of Naval Architects and Marine Engineers

第 3 表 第 16 回海洋開発技術会議分科会

\begin{tabular}{|c|c|c|c|c|c|c|}
\hline DATE/TIME & RoOM 114 & ROOM 111 & RoOM 107 & RoOM 100 & ROOM 300 & ROOM 307 \\
\hline $\begin{array}{c}\text { Monday, } \\
\text { May 7, } 1984 \\
\text { 9:00 a.m.-12:00 }\end{array}$ & $\begin{array}{l}\text { \#1 Lena Guyed } \\
\text { Tower I }\end{array}$ & $\begin{array}{l}\text { \#2 Dynamics of } \\
\text { Offshore } \\
\text { Structures }\end{array}$ & $\begin{array}{c}\text { \#3 Water Treatment/ } \\
\text { Diver Tools }\end{array}$ & $\begin{array}{l}\text { \#4 Offishore } \\
\text { Pipelines }\end{array}$ & \#5 Arctic Islands & $\begin{array}{l}\text { \#6 In Situ Soil } \\
\text { Testing }\end{array}$ \\
\hline $\begin{array}{c}\text { Monday } \\
\text { May } 7,1984 \\
\text { 2:00 p.m.-5:00 p.m. } \\
\end{array}$ & $\begin{array}{l}\text { \#7 Lena Guyed } \\
\text { Tower } 11\end{array}$ & \#8 Ice Forces & $\begin{array}{l}\text { \#9 Marine } \\
\text { Geotechniques }\end{array}$ & $\begin{array}{c}\text { \#10 Marine Geology } \\
\text { and Seafloor } \\
\text { Processes }\end{array}$ & $\begin{array}{l}\text { \#11 Arctic } \\
\text { Operations }\end{array}$ & $\begin{array}{l}\text { \#12 Materials" } \\
\text { Technology }\end{array}$ \\
\hline $\begin{array}{c}\text { Tuesday } \\
\text { May } 8,1984 \\
\text { 9:00 a.m.-12:00 }\end{array}$ & $\begin{array}{l}\# 13 \text { Limited } \\
\text { Driving Force } \\
\text { in Ice }\end{array}$ & $\begin{array}{c}\text { \#14 High Resolution } \\
\text { Geophysics ! }\end{array}$ & $\begin{array}{l}\text { \#15 Subsea } \\
\text { Completions }\end{array}$ & $\begin{array}{l}\text { \#16 Vessel Stability } \\
\text { and Dynamics }\end{array}$ & \#17 Marine Risers & $\begin{array}{l}\text { \#18 Welding } \\
\text { Technology }\end{array}$ \\
\hline $\begin{array}{c}\text { Tuesday } \\
\text { May } 8,1984 \\
\text { 2:00 p.m.-5:00 p.m. }\end{array}$ & $\begin{array}{l}\text { \#19 Deep Water } \\
\text { Well }\end{array}$ & $\begin{array}{c}\# 20 \text { High Resolution } \\
\text { Geophysics } \|\end{array}$ & $\begin{array}{l}\text { \#21 Platform } \\
\text { Construction }\end{array}$ & $\begin{array}{l}\text { \#22 Mooring and } \\
\text { Anchoring }\end{array}$ & $\begin{array}{l}\text { \#23 Corrosion } \\
\text { Fatigue }\end{array}$ & $\begin{array}{c}\text { \#24 Marine Minerals } \\
\text { Mining }\end{array}$ \\
\hline $\begin{array}{l}\text { Wednesday, } \\
\text { May } 9,1984 \\
\text { 9:00 a.m.-12:00 }\end{array}$ & $\begin{array}{l}\text { \#25 Lithology and } \\
\text { Seismic Reflectivity }\end{array}$ & $\begin{array}{l}\text { \#26 Floating } \\
\text { Production I }\end{array}$ & $\begin{array}{l}\text { \#27 Drilling and } \\
\text { Completions }\end{array}$ & $\begin{array}{l}\text { \#28 Arctic Drilling } \\
\text { Units }\end{array}$ & \#29 Foundations & $\# 30$ Wave Forces \\
\hline $\begin{array}{c}\text { Wednesday, } \\
\text { May } 9,1984 \\
\text { 2:00 p.m.-5:00 p.m. }\end{array}$ & $\begin{array}{l}\text { \#31 Seismic } \\
\text { Technology }\end{array}$ & $\begin{array}{l}\text { \#32 Floating } \\
\text { Production II }\end{array}$ & $\begin{array}{l}\text { \#33 Risk and } \\
\text { Reliability }\end{array}$ & $\begin{array}{l}\text { \#34 Wave and } \\
\text { Current Loads }\end{array}$ & $\begin{array}{c}\text { \#35 Foundations } \\
\text { on Calcareous } \\
\text { Soils } \\
\end{array}$ & \\
\hline
\end{tabular}

第 2表 O T C の規模

\begin{tabular}{l|r|r|r|r|r|r}
\hline & $\begin{array}{l}\text { 第 1 回 } \\
\text { 1969第 5回 }\end{array}$ & 1973第10回 & 第14回 & 第15回 & 第16回 \\
1978年 & $\begin{array}{r}1982 \text { 年 } \\
1983 \text { 年 } \\
1984 \text { 年 }\end{array}$ \\
\hline 参 加者 数 & 4,200 & 22,000 & 70,000 & 110,000 & 60,000 & 2,500 \\
発表論文数 & 120 & 180 & 300 & 250 & 190 & 180 \\
出 展 数 & 200 & 850 & 1,800 & 2,900 & 2,500 & - \\
\hline
\end{tabular}

\section{第 4 表 海洋鉱物資源採鉱分科会}

\section{In-Situ Soil Testing}

Room 307

chairmen:

Robert J. Taylor (Naval Civil Eng. Lab.)

OTC

4676 Self-Bored Pressuremeter Testing in the Arctic Offshore

J.M.O. Huges, Western Geosystems Inc.; M.G. Jefferies, Gulf Canada Resources Inc.; and D.L. Morris, Foundex Explorations Inc.

4677 Three Years' Experience With the Offshore Self-Boring Pressuremeter

F. Brucy, J.B. Fay, and P. Le Tirant, Inst. Francais de Petrole

4678 Cyclic Pressuremeter Tests for Cyclic Lateral Loads J.L. Briaud, and K. Riner, Texas A\&M U.; and S. Ohya, OYO Corp. USA

4679 Ambient Pressure Sampler System for Deep-0cean Soil Investigation H.M. Zuidberg, W.H. Schrier, and W.H. Pieters, Fugro B.V

4680 The Suspension PS Velocity Logging System S. Ohya, K: Ogura, and T. Imai, OYO Corp. USA

4681 Development of In-Situ Measuring Apparatus of Geotechnical Elements of Sea Floor (IMAGES)

K. Tsurusaki, Natl. Research Inst. for Pollution \& Resources; F. Itoh, Government Industrial Research Inst.; and T. Yamazaki, Natl. Research Inst. for Pollution \& Resources

* 正会員 公害資源研究所資源第 4 部

** 出典: 第 10 回OTCプログラム, 採鉱と 保安 $(29$ 巻 10 号, p. 529,1983$)$, 及び第 16回OTCプログラム,なお 1984年参加 者数については事務局談。

*** "The Oil Daily", May 8, 1984 the Gorda Ridge Area

R.G. Beauchamp, U.S. Dept. of the Interior

4780 Atlantis-11-Deep's Metal Reserves and Their Evaluation N.A. Odunton, United Nations in Japan
くり昨年更新された掘削水深記録 ( 米国二 ニージャージー沖約 $160 \mathrm{~km}$ の水深約 2,000 $\mathrm{m}$ の海域での掘削記録 ) 一分科会＃19

(3)新しい海底石油生産システムとして注
( 数字は概数 )

\section{第 5 表 現位置土質測定技術分科会}

\section{Marine Minerals Mining}

Room 307

\section{chairmen:}

J. Robert Moore (Univ. of Texas)

Jin S. Chung (Colorado School of Mines)

OTC

(2)スクリップス海洋 研究所が中心となり

実施されてきた深海

掘削計画 (DSDP)

に引続き新たに開始 された海洋掘削計画 (ODP :Ocean Dri lling Program)テキサスA＆M大学 が主体となり1983年 から15年間実施する 計画一についてー 分科会＃10

また，海底石油開 発に関連して,

(1)エクソン社が昨 年米国ルイジアナ沖 約 $180 \mathrm{~km}$ の水深約 $300 \mathrm{~m}$ の海域に完成 させたガイドタワープ ラットホーム (guyed tower platform ) 一分科会, \#1, \#7 (2)シェル社によと

4777 Ore Assays of Massive Sulfides From Three Spreading Centers C.L. Morgan and B.W. Selk, Lockheed Advanced Marine Systems Div.

4778 Geological Perspectives of Metalliferous Sulfides: Offshore Exploration in

4779 A Development Scenario for Mining in the Gorda Ridge Area M.J. Cruickshank and J.P. Zippin, Minerals Management Service M. Guney, U. of Petroleum and Minerals; $Z$. Nawab, Saudi-Sudanese Red Sea Commission; and M.A. Marhoun, U. of Petroleum and Minerals

4781 A Methodology for Mineral Resources Inventory in the Exclusive Economic Zone, and Its Application to the West and Central African EEZ

4782 Research and Development Project of Manganese Nodule Mining System H. Takahara, K. Handa, Ministry of Intl. Trade \& Industry; K. Ishii, Metal Mining Agency of Japan; and E. Kuboki, Ministry of Intt. Trade \& Industry

目されている浮遊式生産システム一 分科

会\#26,\#32

などが挙げられる。 